\title{
ATHEROSCLEROSIS RISK FACTORS IN MALE PATIENTS QUALIFIED FOR PERCUTANEOUS STENTING OF LOWER EXTREMITY ARTERIES. A RETROSPECTIVE COHORT STUDY
}

\author{
CZYNNIKI RYZYKA MIAŻDŻYCY U MĘŻCZYZN KWALIFIKOWANYCH \\ DO PRZEZSKÓRNEGO STENTOWANIA TĘTNIC KOŃCZYN DOLNYCH. \\ BADANIE RETROSPEKTYWNE
}

\footnotetext{
${ }^{1}$ Student Scientific Group, Chair and Clinic of Vascular and Internal Diseases, Faculty of Health Sciences, Ludwik Rydygier Collegium Medicum in Bydgoszcz, Nicolaus Copernicus University in Toruń, Poland

${ }^{2}$ Clinic of Vascular and Internal Diseases, Jan Biziel University Hospital No. 2, Bydgoszcz, Poland

${ }^{3}$ Chair of Vascular and Internal Diseases, Faculty of Health Sciences, Ludwik Rydygier Collegium Medicum in Bydgoszcz, Nicolaus Copernicus University in Torun, Poland
}

\begin{abstract}
S u m m a r y
Objectives. Leg ischemia is the third leading cause of atherosclerotic cardiovascular morbidity, concerning about $20-30 \%$ of the elderly population. Recognition of its risk factors helps in early diagnosis and patient management. The aim of this study was to determine the prevalence of respective atherosclerosis risk factors among patients with peripheral artery disease (PAD) referred for lower limb endovascular revascularization and compare their prevalence with the data obtained in large epidemiological investigations and in patients with atherosclerosis manifestation in coronary and cerebral vascular beds.

Material and methods. Medical documentation for 73 male patients with PAD after a first endovascular intervention was evaluated retrospectively, and the prevalence of atherosclerosis risk factors found was compared with historical control groups from the literature.

Results. The patients studied presented significantly

mellitus than in the POLSCREEN, WOBASZ and NATPOL PLUS studies, significantly greater prevalence of hypertension than in WOBASZ and NATPOL PLUS, significantly greater prevalence of dyslipidemia than in POLSCREEN and NATPOL PLUS, significantly lower prevalence of BMI $\geq 25 \mathrm{~kg} / \mathrm{m}^{2}$ than in POLSCREEN, and greater than in NATPOL PLUS. In comparison to patients with coronary artery disease (CAD), individuals with PAD had a lower prevalence of hypertension and overweight and/or obesity, but greater occurrence of a current smoking habit and dyslipidemia.

Conclusions. Patients with PAD who were qualified for endovascular therapy presented greater prevalence of atherosclerosis risk factors and multisite vascular disease manifestation than various general Polish populations and subjects with CAD, which suggests the need for the improved management of these patients.
\end{abstract} greater prevalence of a current smoking habit and diabetes
Cele. Przewlekłe niedokrwienie kończyn dolnych (PNKD) jest trzecim, co do częstości, schorzeniem sercowonaczyniowym, dotyczącym około $20-30 \%$ dorosłej populacji. Określenie czynników ryzyka PNKD jest istotne dla wczesnej diagnozy i właściwego leczenia chorych. Celem pracy było porównanie częstości występowania poszczególnych czynników ryzyka u pacjentów leczonych wewnątrznaczyniowo $\mathrm{z}$ powodu PNKD $\mathrm{z}$ danymi 
pochodzącymi z dużych badań epidemiologicznych w Polsce dotyczących populacji ogólnej, pacjentów z chorobą naczyń wieńcowych i mózgowych.

Materiał i metody. Dokonano retrospektywnej oceny dokumentacji medycznej 73 mężczyzn leczonych po raz pierwszy wewnątrznaczyniowo $\mathrm{z}$ powodu PNKD, a stwierdzoną częstość występowania głównych czynników ryzyka miażdżycy porównano $\mathrm{z}$ danymi z piśmiennictwa.

Wyniki. Badani pacjenci z PNKD znamiennie częściej palili tytoń i mieli cukrzycę w porównaniu z wyniki polskich badań epidemiologicznych, takich jak: POLSCREEN, WOBASZ i NATPOL PLUS. Prezentowali oni znamiennie częstsze występowania nadciśnienia tętniczego niż w badaniach WOBASZ i NATPOL PLUS, większą częstość dyslipidemii niż w badaniach POLSCREEN i NATPOL PLUS oraz większą częstość BMI $\geq 25 \mathrm{~kg} / \mathrm{m}^{2}$ niż w badaniu POLSCREEN i mniejszą niż w badaniu NATPOL PLUS. W porównaniu $\mathrm{z}$ pacjentami $\mathrm{z}$ chorobą wieńcową (CHW) pacjenci $\mathrm{z}$ PNKD mieli znamiennie rzadziej nadciśnienie tętnicze, nadwagę lub otyłość, ale częściej palili i mieli dyslipidemię.

Wnioski. Pacjenci z PNKD prezentowali większą częstość i nasilenie czynników ryzyka miażdżycy oraz wielopoziomowej manifestacji miażdżycy niż osoby $\mathrm{z}$ populacji ogólnej oraz pacjenci z CHW, co wskazuje na konieczność poprawy leczenia zachowawczego w tej grupie chorych.

Key words: peripheral artery disease, lower limb ischemia, atherosclerosis risk factors, epidemiological studies

Stowa kluczowe: choroba naczyń obwodowych, przewlekłe niedokrwienie kończyn dolnych, czynniki ryzyka, badania epidemiologiczne

\section{INTRODUCTION}

Lower extremity peripheral artery disease (PAD) is the third leading cause of atherosclerotic cardiovascular morbidity, following coronary artery disease (CAD) and stroke. However, among patients with only one location of significant atherosclerotic lesions, cardiovascular mortality is significantly higher with PAD (11.3\%) than with cerebrovascular disease (6\%) or CAD (5.1\%) [1]. PAD has become a global problem due to the increase in life expectancy and morbidity in the 21st century [2]. Among those aged 75 , the total percentage of PAD patients amounts to $30 \%$, of whom, however, only $30 \%$ again are symptomatic [3-5]. In a recent meta-analysis of 34 investigations based on 112,027 participants, the PAD prevalence in men in high-income countries was $5.41 \%$ (3.41-8.49\%) at age $45-49$ and $18.83 \%$ (12.03-28.25\%) at age 85-89 [2]. Atherosclerotic cardiovascular diseases develop in response to a combination of several risk factors, such as age/gender, smoking habits, dyslipidemia, hypertension, diabetes, mellitus, overweight/obesity, and low physical activity $[5,6]$. It is generally known that the presence of more risk factors in one person increases his or her risk of the occurrence of a cardiovascular event or death. For this reason, interactive risk calculators, e.g. SCORE or HeartScore, are proposed to improve the prediction of cardiovascular events after 10 years in asymptomatic persons aged mainly 40-65. The main purpose for using these calculators is to avoid both under- and overtreatment [6]. However, such multifactorial risk assessment is more effective at predicting heart attacks than strokes, and has significantly less usefulness in predicting the need for lower extremity revascularization. This suggests that the risk factors for PAD may be different to those for CAD or that there are differences in the extent of the influence of respective risk factors on atherosclerosis manifestation in various vascular beds [7, 8]. It is also possible that, due to differences in the histology of the aorta, iliac and femoral arteries, the respective atherosclerosis risk factors among patients with PAD show different effects on the severity of the lesions in respective vascular territories [7]. Less knowledge concerning the risk factors for PAD than those for CAD may be one of the significant reasons for primary amputation still being the method of choice in the treatment of critical limb ischemia in $5-20 \%$ of patients, with a $4-30 \%$ risk of periprocedural death and a $30-45 \%$ risk of 12 -month mortality $[4,5]$.

There are known to be several types of atherosclerosis manifestation, such as myocardial infarction, ischemic stroke, or peripheral, including visceral, artery disease. They may overlap (polyvascular disease, multisite atherosclerosis), in which case the risk of cardiovascular event and mortality increases significantly $[4,5, \quad 9-14]$. Sometimes, the respective types of vascular disease prevalence demonstrate a family association, which suggests that they may be related to composite domestic factors; not only genetic, but also, for example, active and passive smoking habits, diet, overeating, low physical activity, stress, alcohol abuse, etc. These factors should be identified in patients with PAD and used in an educational process that not only concerns the patients, but also their families. In other words, the recognition of the predominant risk factors 
in patients with respective type of atherosclerosis manifestation would not only improve our knowledge of vascular diseases, but may also help to individualize the prevention strategy for vascular disease. It is frequently difficult to obtain from elderly people with PAD information concerning the kind of atherosclerosis clinical presentation experienced by their parents, although it is usually too late to implement prevention measures in such a population. However, we can identify the younger family members of patients treated due to leg ischemia and recommend a preventive strategy to them with the emphasis on the most important factors, e.g. tobacco use. The value of such treatment would also result from the fact that we still not have guidelines on how to screen the population in regard to PAD risk and prevalence and, because of this, the number of PAD patients is underestimated and this group remains undertreated [15]. The premises discussed above represent the rationale behind our analysis, the aim of which was to determine the prevalence of respective atherosclerosis risk factors among patients referred for lower limb endovascular revascularization and compare their prevalence with the data obtained from large investigations on the general population and patients with various syndromes of atherosclerosis manifestation in coronary and cerebral vascular beds.

\section{METHODS}

We retrospectively evaluated the medical documentation of 73 consecutive male patients with PAD treated endovascularly between 2008 and 2013 with stenting due to lower extremity artery atherosclerosis. The inclusion criteria were as follows: a) first-time stenting of lower extremity arteries due to chronic leg ischemia in the course of atherosclerosis; b) blood creatinine concentration within normal range; c) complete follow-up for at least one year with visits at $1,3,6$, and 12 months after the endovascular procedure, and further follow-up at least 6 months after that, twice in the year. The exclusion criteria were: a) stent occlusion due to thrombosis or fracture; b) lack of compliance with changes suggested by the medical team (e.g. to lifestyle or medication); and c) the need for surgical revascularization during the follow-up after stenting.

The following parameters were analyzed: age, smoking habits, hypertension, dyslipidemia (defined as increased blood low-density lipoprotein [LDL] cholesterol concentration above $100 \mathrm{mg} / \mathrm{dl}$, and/or triglyceride blood concentration above $150 \mathrm{mg} / \mathrm{dl}$, or hypolypemic treatment on admission for a first endovascular procedure), diabetes mellitus, body mass index (BMI), and a history of CAD and stroke.

\section{MAIN OUTCOMES MEASURED}

The prevalence of respective atherosclerosis risk factors in comparison to the data from large epidemiological studies on Polish populations (POLSCREEN, 400 Towns Project, WOBASZ, NATPOL PLUS) [16], as well as a comparison of these risk factors to recent data concerning the frequency of atherosclerosis risk factors in patients with chronic coronary syndromes (POLSCREEN CAD) [16], acute coronary syndromes [17], both with sustained ST-segment elevation (STEMI) [18] and with non-sustained ST-segment elevation (NSTEMI) [19], in addition to acute cerebral manifestations of vascular disease (a large Polish study was not available) [20].

\section{ETHICS}

The study protocol was approved by the local Bioethics Committee (agreement number KB139/2014). All procedures were conducted in compliance with the Declaration of Helsinki.

\section{STATISTICAL ANALYSIS}

Statistical analysis was conducted using a licensed version of statistical software STATISTICA PL 10.0 for Windows. The normal distribution of the study variables was checked using the Shapiro-Wilk test. The results were mainly presented as $\mathrm{n}, \%$ and the mean \pm standard deviation (SD). The statistical significance of differences between the patients in our own study and historical control groups (references data) was performed using a Chi-square test.

\section{RESULTS}

Seventy-three male patients were included in the analysis. They had qualified for endovascular treatment of lower limb ischemia due to life-activity-limiting claudication $(\mathrm{n}=55,75 \%)$ and critical limb ischemia $(\mathrm{n}=18,25 \%)$. In comparison to general but various Polish populations (historical control group) (Tab. I), 
our patients presented: (a) significantly greater prevalence of a current smoking habit and diabetes mellitus than those in all the epidemiological investigations chosen for comparison, (b) significantly greater prevalence of hypertension than in the WOBASZ and NATPOL PLUS studies, (c) significantly greater prevalence of dyslipidemia than that found in the POLSCREEN and NATPOL PLUS studies, and (d) significantly greater prevalence than in the NATPOL PLUS study for both overweight and/or obesity (BMI $\geq 25 \mathrm{~kg} / \mathrm{m}^{2}$ ) and obesity (BMI $\geq 30$ $\mathrm{kg} / \mathrm{m}^{2}$ ) (Tab. I).
In the next part of the analysis (Tab. II), we compared the prevalence of respective atherosclerosis risk factors in the analyzed patients with PAD with the literature data concerning individuals with various clinical manifestations of atherosclerosis in other vascular beds (chronic and acute coronary syndromes and ischemic stroke). Our patients with PAD, in comparison to patients with chronic CAD (POLSCREEN CAD), had a lower prevalence of hypertension and overweight and/or obesity, but a greater occurrence of a current smoking habit and dyslipidemia (Tab. II) [16]. In comparison to patients

Table 1. Prevalence of atherosclerosis risk factors in male patients treated endovascularly due to lower limb ischemia and the prevalence of such conditions in selected epidemiological studies. On the base of data presented by Cieśliński et al. [16]

Tabela 1. Częstość poszczególnych czynników ryzyka miażdzycy u pacjentów leczonych wewnątrznaczyniowo z powodu przewlektego niedokrwienia kończyn dolnych oraz $w$ wybranych polskich badaniach epidemiologicznych wg Cieślińskiego i wsp. [16]

\begin{tabular}{|c|c|c|c|c|c|}
\hline Parameter & $\begin{array}{c}\text { Own study } \\
\text { Badania wlasne } \\
(\mathrm{n}=73)\end{array}$ & $\begin{array}{c}\text { POLSCREEN } \\
(\mathrm{n}=\mathbf{2 4 6 , 3 1 3})\end{array}$ & $\begin{array}{l}400 \text { Towns Project } \\
\text { Projekt } 400 \text { miast } \\
\quad(n=1,708)\end{array}$ & $\begin{array}{r}\text { WOBASZ } \\
(\mathrm{n}=6,392)\end{array}$ & $\begin{array}{l}\text { NATPOL PLUS } \\
\quad(\mathbf{n}=\mathbf{3 , 0 5 0 )}\end{array}$ \\
\hline $\begin{array}{l}\text { Age (years); range or mean } \pm \mathrm{SD} \\
\text { Wiek (lata); przedział lub średnia } \pm \mathrm{SD}\end{array}$ & $62.8 \pm 8.5$ & $\begin{array}{c}\geq 35 \text { years } \\
\geq 35 \text { lat }\end{array}$ & $18-92$ & $20-74$ & $18-94$ \\
\hline $\begin{array}{l}\text { Current smoking }(\mathrm{n}, \%) \\
\text { Aktualne palenie }(\mathrm{n}, \%)\end{array}$ & $40(55 \%)$ & $29.3 \%^{+}$ & $22.9 \%^{+}$ & $49.4 \% *$ & $40 \%^{+}$ \\
\hline $\begin{array}{l}\text { Hypertension (n, \%) } \\
\text { Nadciśnienie (n, \%) }\end{array}$ & $51(70 \%)$ & $71.2 \%$ & $65.8 \%$ & $42 \%+$ & $29 \%+$ \\
\hline $\begin{array}{l}\text { Diabetes (n, \%) } \\
\text { Cukrzyca (n, \%) }\end{array}$ & $20(27 \%)$ & $16 \% *$ & $7 \%^{+}$ & $7 \%(16 \%)^{\mathrm{a}}$ & $5.6 \%+$ \\
\hline $\begin{array}{l}\text { Dyslipidemia (n, \%) } \\
\text { Dyslipidemia (n, \%) }\end{array}$ & $57(78 \%)$ & $67.1 \% *$ & $69.9 \%$ & $74 \%$ & $60 \%^{+}$ \\
\hline LDL $\geq 100 \mathrm{mg} / \mathrm{dl}(\mathrm{n}, \%)$ & $50(69 \%)$ & & & $60 \%$ & $60.1 \%$ \\
\hline $\begin{array}{l}\text { Triglycerides } \\
\geq 150 \mathrm{mg} / \mathrm{dl}(\mathrm{n}, \%) \\
\text { Trójglicerydy } \\
\geq 150 \mathrm{mg} / \mathrm{dl}(\mathrm{n}, \%) \\
\end{array}$ & $19(26 \%)$ & & & & $30.1 \%$ \\
\hline $\begin{array}{l}\text { Fasting glucose } \\
\geq 100 \mathrm{mg} / \mathrm{dl}(\mathrm{n}, \%) \\
\text { Glukoza na czczo } \\
\geq 100 \mathrm{mg} / \mathrm{dl}(\mathrm{n}, \%)\end{array}$ & $35(48 \%)$ & & $39.7 \%$ & & \\
\hline BMI $\left(\mathrm{kg} / \mathrm{m}^{2}\right)$ & $27.6 \pm 5.0$ & $27.9 \pm 4.0$ & & & \\
\hline BMI $\geq 25 \mathrm{~kg} / \mathrm{m}^{2}(\mathrm{n}, \%)$ & $49(67 \%)$ & $76.6 \% *$ & $73.7 \%$ & $61.6 \%$ & $52.7 \% *$ \\
\hline BMI $\geq 30 \mathrm{~kg} / \mathrm{m}^{2}(\mathrm{n}, \%)$ & $21(29 \%)$ & $26.8 \%$ & $27.3 \%$ & $20.2 \%$ & $19 \% *$ \\
\hline $\begin{array}{l}\text { History of myocardial infarction }(\mathrm{n}, \%) \\
\text { Przebyty zawał serca } \\
(\mathrm{n}, \%)\end{array}$ & $32(44 \%)$ & $13 \%^{+}$ & & & \\
\hline $\begin{array}{l}\text { Past stroke (n, \%) } \\
\text { Przebyty udar (n, \%) }\end{array}$ & $8(11 \%)$ & $3 \%{ }^{+}$ & & & \\
\hline $\begin{array}{l}\text { History of PAD (n, \%) } \\
\text { Wywiad niedokrwienia kończyn }\end{array}$ & $73(100 \%)$ & $11 \%^{+}$ & & & \\
\hline
\end{tabular}

Abbreviations: $\mathrm{SD}=$ standard deviation; ${ }^{\mathrm{a}}=$ patients $65-74$ years of age $; \mathrm{LDL}=$ low-density lipoprotein; $\mathrm{BMI}=$ body mass index; PAD = peripheral artery disease; statistical significance of the difference between our results and those obtained in respective epidemiological investigations carried out by $\mathrm{Chi}^{2}$ test: $*=\mathrm{p}<0.05 ;^{+}=\mathrm{p}<0.001$

Skróty: SD = odchylenie standardowe; ${ }^{\mathrm{a}}=$ pacjenci w wieku 65-74 lat; LDL = cholesterol w lipoproteinach o niskiej gęstości; BMI = wskaźnik masy ciała; PAD = choroba naczyń obwodowych; znamienność statystyczna różnicy między wynikami własnymi oraz danymi z poszczególnych badań epidemiologicznych w teście $\mathrm{Chi}^{2}: *=\mathrm{p}<0.05 ;^{+}=\mathrm{p}<0,001$ 
on the Polish Registry of Acute Coronary Syndromes (PL-ACS) [17], our subjects appeared to have had a more frequent occurrence of: a smoking habit, hypertension, dyslipidemia, obesity, and past presented significantly more frequently with a smoking habit, dyslipidemia and past myocardial infarction (Tab. II).

Table 2. Prevalence of atherosclerosis risk factors in male patients treated endovascularly due to lower limb ischemia and the prevalence of such conditions in selected studies on stable coronary artery disease, acute coronary syndromes and ischemic stroke. On the base of data presented in respective references [16-20]

Tabela 2. Czesstość poszczególnych czynników ryzyka miażdzycy u pacjentów leczonych wewnatrznaczyniowo z powodu przewlektego niedokrwienia kończyn dolnych oraz $w$ wybranych badaniach u pacjentów ze stabilna choroba wieńcowa, ostrymi zespołami wieńcowymi i udarem niedokrwiennym. Na podstawie danych z piśmiennictwa [16-20].

\begin{tabular}{|c|c|c|c|c|c|c|c|}
\hline Parameter & $\begin{array}{c}\text { Own study } \\
(\mathrm{n}=73 \text { males })\end{array}$ & $\begin{array}{c}\text { POLSCREEN } \\
\text { CAD } \\
(\mathbf{n}=\mathbf{5 8 , 3 5 9} \\
\text { males) }[16]\end{array}$ & $\begin{array}{c}\text { PL-ACS } \\
\text { registry } \\
2012(n= \\
4,144, \\
59 \% \text { male })[17]\end{array}$ & $\begin{array}{c}\text { STEMI }<65 \text { yr } \\
(\mathrm{n}=280 \text { males }) \\
{[18]}\end{array}$ & $\begin{array}{c}\text { STEMI }>65 \text { yr } \\
(n=415 \text { males }) \\
{[18]}\end{array}$ & $\begin{array}{c}\text { NSTEMI > 80 yr } \\
(\mathrm{n}=13,707 \\
39.7 \% \text { male }) \\
{[19]}\end{array}$ & $\begin{array}{c}\text { Ischemic } \\
\text { stroke } \\
(\mathbf{n}=\mathbf{5 7 1}, \\
\mathbf{6 5 \%} \text { male }) \\
{[20]}\end{array}$ \\
\hline $\begin{array}{l}\text { Age (years); range } \\
\text { or mean } \pm \text { SD } \\
\text { Wiek (lata); } \\
\text { przedział lub } \\
\text { średnia } \pm \text { SD }\end{array}$ & $62.8 \pm 8.5$ & $63 \pm 10$ & $68 \pm 12$ & $55 \pm 6.0$ & $74.6 \pm 6.3$ & $80-105$ & $\begin{array}{c}72.5 \pm 8.5 \\
52-96\end{array}$ \\
\hline $\begin{array}{l}\text { Current smoking } \\
(\mathrm{n}, \%) \\
\text { Aktualne palenie } \\
(\mathrm{n}, \%)\end{array}$ & $40(55 \%)$ & $22 \%^{+}$ & $18 \%^{+}$ & $50.4 \%$ & $21.2 \%{ }^{+}$ & $12.8 \%^{+}$ & $7.5 \%+$ \\
\hline $\begin{array}{l}\text { Hypertension } \\
(\mathrm{n}, \%) \\
\text { Nadciśnienie } \\
(\mathrm{n}, \%)\end{array}$ & $51(70 \%)$ & $80 \% *$ & $52 \% *$ & $67.9 \%$ & $77.1 \%$ & $72.8 \%$ & $69.2 \%$ \\
\hline $\begin{array}{l}\text { Diabetes (n, \%) } \\
\text { Cukrzyca (n, \%) }\end{array}$ & 20 (27\%) & $22 \%$ & $29 \%$ & $13.9 \% *$ & $24.3 \%$ & $30.6 \%$ & $19.3 \%$ \\
\hline $\begin{array}{l}\text { Dyslipidemia } \\
(\mathrm{n}, \%) \\
\text { Dyslipidemia } \\
(\mathrm{n}, \%)\end{array}$ & $57(78 \%)$ & $48 \%^{+}$ & $32 \%{ }^{+}$ & $64.3 \% *$ & $52.8 \% *$ & $33.5 \%{ }^{+}$ & $64.5 \% *$ \\
\hline $\begin{array}{l}\mathrm{BMI} \geq 25 \mathrm{~kg} / \mathrm{m}^{2} \\
(\mathrm{n}, \%)\end{array}$ & $49(67 \%)$ & $79 \% *$ & & & & & \\
\hline $\begin{array}{l}\mathrm{BMI} \geq 30 \mathrm{~kg} / \mathrm{m}^{2} \\
(\mathrm{n}, \%)\end{array}$ & $21(29 \%)$ & $29 \%$ & $19 \% *$ & $15 \%+$ & $11.8 \%^{+}$ & $14.9 \%^{+}$ & \\
\hline $\begin{array}{l}\text { History of } \\
\text { myocardial } \\
\text { infarction (n, \%) } \\
\text { Przebyty zawał } \\
\text { serca (n, \%) }\end{array}$ & $32(44 \%)$ & & $26 \%^{+}$ & $28.9^{*}$ & $37.1 \%$ & $22.4 \%^{+}$ & $15.8 \%^{+}$ \\
\hline $\begin{array}{l}\text { Past stroke }(\mathrm{n}, \%) \\
\text { Przebyty udar } \\
(\mathrm{n}, \%)\end{array}$ & $8(11 \%)$ & & & & & & $14.2 \%$ \\
\hline
\end{tabular}

Abbreviations: PL-ACS registry $=$ Polish Registry of Acute Coronary Syndromes; STEMI $=$ ST segment elevation myocardial infarction; NSTEMI = non-ST segment elevation myocardial infarction; SD = standard deviation; $\mathrm{BMI}=$ body mass index; statistical significance of the difference between own results and those obtained in respective epidemiological investigations carried out by $\mathrm{Chi}^{2}$ test: $*=\mathrm{p}<0.05 ;^{+}=\mathrm{p}<0.001$.

Skróty: PL-ACS registry = Polski Rejestr Ostrych Zespołów Wieńcowych; STEMI = ostry zwał serca z przetrwałym uniesieniem odcinka ST; NSTEMI = ostry zawał serca bez przetrwałego uniesienia odcinka ST; SD = odchylenie standardowe; BMI =wskaźnik masy ciała; znamienność statystyczna różnicy między wynikami własnymi oraz danymi z poszczególnych badań epidemiologicznych $\mathrm{w}$ teście $\mathrm{Chi}^{2}: *=\mathrm{p}<0.05 ;^{+}=\mathrm{p}<0,001$.

myocardial infarction (Tab. II). Similar factors, with the exception of hypertension, were more prevalent in the patients in our study than in individuals with STEMI [18] and in octogenarians with NSTEMI [19]. Compared with the historical control, the patients in our study with PAD with acute ischemic stroke [20]

\section{DISCUSSION}

In our study we compared the prevalence of respective traditional atherosclerosis factors in male PAD patients referred for elective endovascular intervention with their reported frequency in various 
Polish epidemiological investigations on general large populations (Tab. I) and in groups of individuals with different sites and types of atherosclerosis manifestation, such as stable and unstable coronary artery disease, and with ischemic stroke (Tab. II).

Our analysis showed that in comparison to general Polish populations our patients with advanced and symptomatic PAD were more frequently diabetics (on average 1.5-4.8 times), smokers (on average 1.3-2 times), and dyslipidemic (on average 1.05-1.3 times), but they presented a lower (by 15\%) prevalence of overweight and/or obesity (BMI $\geq 25 \mathrm{mg} / \mathrm{kg}^{2}$ ) than in the POLSCREEN study. The last observation may be seen as surprising but a lower odds ratio (OR) for being overweight and being obese in PAD subjects compared to those in the control group had previously been reported [7]. Our other observations also corroborate data obtained by other researchers. In a recent meta-analysis of 34 papers by Fowkes et al. [2], a smoking habit was an important risk factor for PAD in both high-income and low-middle-income countries, with meta-OR for current tobacco use of 2.72 (95\% CI 2.39-3.09) and 1.42 (1.25-1.62), respectively, followed by diabetes mellitus (1.88 [1.66-2.14] vs 1.47 [1.291.68]), hypertension (1.55 [1.42-1.71] vs 1.36 [1.241.50]), and hypercholesterolemia (1.19 [1.07-1.33] vs 1.14 [1.03-1.25]). In a study by Poredoš et al. [8], cigarette smoking and diabetes mellitus also represented the greatest risks for PAD. In other work, age, duration of diabetes, smoking habits, high blood pressure and an $\mathrm{HbA} 1 \mathrm{c}>7 \%$ were significant predictors of PAD, while obesity did not correlate with PAD [21]. Whereas, in a study by Bez and Navarro [10], of the patients with PAD investigated, $86 \%$ had hypertension, $66 \%$ exposure to tobacco smoke, $47 \%$ diabetes, $65 \%$ dyslipidemia, $24 \%$ coronary artery disease, $16 \%$ renal failure, and $60 \%$ a family history of cardiovascular disease [10]. It seems worth underlining at this point that in trying to explain such a high incidence of hypertension in patients with PAD $(70 \%$ in our study of patients with normal creatinine levels) in comparison with other populations, the potential coexistence of renal artery stenosis (RAS) should be taken into account [14] because, in an analysis by Endo et al. [22] of 410 Japanese patients with PAD, $22.9 \%$ had RAS $>50 \%$ and $11.0 \%$ had RAS $>75 \%$.

Although the above-cited papers report a comparable prevalence of respective cardiovascular risk factors, in a study by Sumner et al. [23] only $38 \%$ of a population with PAD had metabolic syndrome, which doubles the risk of having PAD. On the other hand, in Korean diabetic patients, the PAD prevalence was $3.2 \%$ [24]. Moreover, it is sometimes not possible to determine atherosclerosis risk factors in patients with PAD. Among 1,932 study participants without traditional atherosclerosis risk factors, a low $(\leq 0.9)$ ankle-brachial index (ABI) was found in $176(9 \%)$ cases and a high ABI $(\geq 1.3)$ in $149(7.8 \%)$ cases. Only a lower glomerular filtration rate and higher interleukin-6 level were associated with low ABI with statistical significance, and past smoking (cessation > 10 years) and pulse pressure had a borderline association with low ABI [25].

Our patients with PAD also presented a significantly greater prevalence of past cardiovascular events from other vascular territories than in the general Polish population investigated in the POLSCREEN study (Tab. I). It is obvious because of an atherosclerosis is an systemic disease, and its polyvascular (multisite) manifestation concern 15-60\% of patients with $\mathrm{PAD}$, and PAD presence is recognized as equivalent or at least risk factors for coronary or cerebrovascular diseases [5]. The similar prevalence of previous stroke in our patients with PAD and in individuals with acute ischemic stroke suggests $\mathrm{g}$ PAD recognition as an clinical equivalent of stroke (Tab. II), although such a suggestion would not change PAD patient management due to the same therapeutic targets in the secondary prevention of very high-risk individuals $[5,6]$.

In our study we also tried to test the hypothesis that various traditional atherosclerosis risk factors, although the same for PAD, CAD, and cerebrovascular diseases, differ in the power of the association between them and vascular lesion severity in respective vascular territories [5, 6, 26]. For this purpose we compared the prevalence of respective risk factors in our PAD patients with their prevalence in patients with CAD and ischemic stroke (Tab. II). Our subjects with PAD were more frequently smokers and dyslipidemic than patients with CAD and stroke, but they presented less frequently a BMI above $25 \mathrm{~kg} / \mathrm{m}^{2}$. The other studies also confirmed the predominant effect of smoking habits on PAD occurrence in comparison to the other vascular beds of atherosclerosis manifestation. In a study by Radak et al. [27] the most significant risk factors for PAD were smoking (97\%), hyperlipidemia, and a family history of atherosclerotic disease. In work by Agarwal and Naderi [28], in comparison with CAD patients, subjects with PAD were more frequently 
female, black, and active smokers. Moreover, in this study, patients with PAD had significantly higher serum concentrations of LDL cholesterol and Creactive protein than those with CAD alone [28]. In another study, among patients with chronic splanchnic ischemia, female predominance $(74 \%)$ but a lower incidence of obesity/increased bodyweight (21\%), diabetes mellitus (21\%), hypertension (62\%), and hypercholesterolemia $(53 \%)$ than in patient groups with atherosclerosis of other vascular territories were observed [29].

In spite of some limitations, such as the retrospective type of the analysis and the small sample size, our results regarding male patients with PAD referred for elective endovascular intervention may have several practical implications. First, our results show that the achievement of target levels for controlling traditional atherosclerosis risk factors in the $21^{\text {st }}$ century remains poor. However, elective interventions for lower extremity arteries give an opportunity to identify the atherosclerosis risk factors in respective PAD patients to start secondary prevention, as well as diagnosing the presence of concomitant atherosclerotic lesions in the remaining vascular territories, especially as the effectiveness of the routine management of risk factors in primary care in Poland is very low [30]. The most important target for PAD prevention seems to be stopping smoking, despite the results of a multivariate analysis by Alvarez et al. [31] that showed that after smoking cessation the relative risk of death for those who had quit smoking was $0.20(95 \%$ CI 0.05-0.75) in patients with CAD, 0.0 in those with cerebrovascular disease, and $1.83(95 \%$ CI 0.65-5.15) in those with PAD, which suggests that tobacco withdrawal is associated with a significant decrease in mortality in patients with $\mathrm{CAD}$, but a nonsignificant increase in those with PAD [31].

The benefit for all patients achieving low levels of low-density lipoprotein cholesterol also supports the need for intensive lipid lowering in patients with PAD [5, 6, 32]. Aggressive therapy with statins in patients with PAD has significantly reduced all-cause mortality and the risk of stroke and shows a trend towards decreasing the risk of other cardiovascular end-points [33]. Statins have also been shown to improve survival for one year after vascular surgery [34, 35] and demonstrated a decreased incidence of embolic complications after endovascular aortic repair [34]. In addition, several studies in recent years have shown that statins improved pain-free walking distance, ankle- brachial index values and treadmill exercise time $[8$, 36]. Although Dosluoglu et al. [37] did not find a favorable statins effect on long-term stent or bypass patency and limb salvage, Sohn et al. [38] reported that compared with patients who did not use cholesterollowering agents statin users were $35-43 \%$ less likely to experience lower extremity amputation. In this study, users of other cholesterol-lowering medications were not significantly different in terms of leg amputation risk [38]. Moreover, in another study, statin-treated patients with PAD after endovascular intervention had significantly higher rates of primary patency at 24 months (43\% vs $33 \%$ ), secondary patency (66\% vs $51 \%)$, limb salvage ( $83 \%$ vs $62 \%$ ), and overall survival (77\% vs 62\%) [39]. Identification of atherosclerosis risk factors in PAD patients may also help to identify family members who may be at risk of leg ischemia.

\section{CONCLUSIONS}

1. Patients with PAD who qualified for endovascular therapy presented a greater prevalence of atherosclerosis risk factors and multisite vascular disease manifestation than various Polish populations investigated in large epidemiological studies, which demonstrated the poor achievement of target levels for controlling traditional atherosclerosis risk factors

2. Patients with PAD appeared to have a greater incidence of smoking, dyslipidemia, obesity and a history of prior myocardial infarction than the historical control group with ACS or ischemic stroke, which places them in the highest cardiovascular risk group.

3. Our observations show the need for more careful management of patients with PAD as these individuals, of all those with vascular diseases, are the most likely to be at risk of a cardiovascular event and death. It also seems reasonable to start with education for patients' family members in identifying and controlling atherosclerosis risk factors.

\section{REFERENCES}

1. Cantú-Brito C, Chiquete E, Ruiz-Sandoval JL, et al. Atherothrombotic disease, traditional risk factors, and 4year mortality in a Latin American population: the REACH Registry. Clin Cardiol. 2012;35(8):451-7. doi: 10.1002/clc.22005. 
2. Fowkes FG, Rudan D, Rudan I, et al. Comparison of global estimates of prevalence and risk factors for peripheral artery disease in 2000 and 2010: a systematic review and analysis. Lancet. 2013;382(9901):1329-40. doi: 10.1016/S0140-6736(13)61249-0.

3. Bartuś S, Siudak Z, Brzeziński M, et al. Percutaneous peripheral interventions in patients with multivessel coronary artery disease. Kardiol Pol. 2010;68(10):111521.

4. Norgren L, Hiatt WR, Dormandy JA, TASC II Working Group. Inter-Society Consensus for the Management of Peripheral Arterial Disease (TASC II). J Vasc Surg. 2007;45 Suppl S:S5-67.

5. European Stroke Organisation, Tendera M, Aboyans V, et al. ESC Guidelines on the diagnosis and treatment of peripheral artery diseases: Document covering atherosclerotic disease of extracranial carotid and vertebral, mesenteric, renal, upper and lower extremity arteries: the Task Force on the Diagnosis and Treatment of Peripheral Artery Diseases of the European Society of Cardiology (ESC). Eur Heart J. 2011;32(22):2851-906. doi: 10.1093/eurheartj/ehr211.

6. Perk J, De Backer G, Gohlke H, et al. European Association for Cardiovascular Prevention \& Rehabilitation (EACPR); ESC Committee for Practice Guidelines (CPG). European Guidelines on cardiovascular disease prevention in clinical practice (version 2012). The Fifth Joint Task Force of the European Society of Cardiology and Other Societies on Cardiovascular Disease Prevention in Clinical Practice (constituted by representatives of nine societies and by invited experts). Eur Heart J 2012;33:1635-701. doi: 10.1093/eurheartj/ehs092.

7. Jang SY, Ju EY, Cho SI, et al. Comparison of cardiovascular risk factors for peripheral artery disease and coronary artery disease in the Korean population. Korean Circ J. 2013;43(5):316-28. doi: 10.4070/kcj.2013.43.5.316.

8. Poredoš P, Jezovnik M, Kalodiki E, et al. Medical management of patients with peripheral arterial disease. Int Angiol. 2015;34(1):75-93.

9. Ahn S, Park YJ, Min SI, et al. High prevalence of peripheral arterial disease in Korean patients with coronary or cerebrovascular disease. J Korean Med Sci. 2012;27(6):625-9.

10. Bez LG, Navarro TP. Study of carotid disease in patients with peripheral artery disease. Rev Col Bras Cir. 2014;41(5):311-8. doi: 10.3346/jkms. 2012.27.6.625.

11. Naderi N, Masoomi H, Mozaffar T, Malik S. Patient characteristics and comorbidities associated with cerebrovascular accident following acute myocardial infarction in the United States. Int $\mathrm{J}$ Cardiol. 2014;175(2):323-7. doi: 10.1016/j.ijcard.2014.05.024.

12. Kojima I, Ninomiya T, Hata J, et al. A low ankle brachial index is associated with an increased risk of cardiovascular disease: the Hisayama study. J Atheroscler Thromb. 2014;21(9):966-73.

13. Gronewold J, Hermann DM, Lehmann N, et al. Anklebrachial index predicts stroke in the general population in addition to classical risk factors. Atherosclerosis. 2014;233(2):545-50. doi: 10.1016/j.atherosclerosis. 2014.01.044.

14. Imori $\mathrm{Y}$, Akasaka $\mathrm{T}$, Ochiai $\mathrm{T}$, et al. Co-existence of carotid artery disease, renal artery stenosis, and lower extremity peripheral arterial disease in patients with coronary artery disease. Am J Cardiol. 2014;113(1):30-5. doi: 10.1016/j.amjcard.2013.09.015.

15. Aiman U, Haseen MA, Beg MH, et al. Profile of atherosclerotic risk factors and management in patients of peripheral arterial disease at a tertiary care teaching hospital of north India. Indian J Pharm Sci. 2014;76(6):504-9.

16. Cieśliński A, Pająk A, Podolec P, Rynkiewicz A (red.): Ogólnopolski Program Prewencji Choroby Wieńcowej POLSCREEN. 1st edition, Poznań, Termedia Wydawnictwo Medyczne; 2006, p: 32-38, 49, 59-64, 71, 81-84.

17. Gąsior M, Pres D, Gierlotka M, et al. The influence of diabetes on in-hospital and long-term mortality in patients with myocardial infarction complicated by cardiogenic shock: results from the PL-ACS registry. Kardiol Pol.2012;70(12):1215-24.

18. Sielski J, Janion-Sadowska A, Sadowski M, et al. Differences in presentation, treatment, and prognosis in elderly patients with non-ST-segment elevation myocardial infarction. Pol Arch Med Wewn. 2012;122(6):253-61.

19. Gierlotka M, Gąsior M, Tajstra M, et al. Outcomes of invasive treatment in very elderly Polish patients with non-ST-segment-elevation myocardial infarction from 2003-2009 (from the PL-ACS registry). Cardiol J. 2013;20(1):34-43. doi: 10.5603/CJ.2013.0007.

20. Sanna T, Diener HC, Passman RS, et al. Cryptogenic stroke and underlying atrial fibrillation. N Engl J Med. 2014;370(26):2478-86. doi: 10.1056/NEJMoa1313600.

21. Agarwal AK, Singh M, Arya V, et al. Prevalence of peripheral arterial disease in type 2 diabetes mellitus and its correlation with coronary artery disease and its risk factors. J Assoc Physicians India. 2012;60:28-32.

22. Endo M, Kumakura H, Kanai H, et al. Prevalence and risk factors for renal artery stenosis and chronic kidney disease in Japanese patients with peripheral arterial disease. Hypertens Res. 2010;33(9):911-5. doi: 10.1038/hr.2010.93.

23. Sumner AD, Khalil YK, Reed JF 3rd. The relationship of peripheral arterial disease and metabolic syndrome prevalence in asymptomatic US adults 40 years and older: results from the National Health and Nutrition Examination Survey (1999-2004). J Clin Hypertens (Greenwich). 2012;14(3):144-8. doi: 10.1111/j.17517176.2011.00580.x.

24. Yu JH, Hwang JY, Shin MS, et al. The prevalence of peripheral arterial disease in Korean patients with type 2 diabetes mellitus attending a university hospital. Diabetes Metab J. 2011;35(5):543-50. doi: 10.4093/dmj. 2011.35.5.543.

25. Aboyans V, McClelland RL, Allison MA, et al. Lower extremity peripheral artery disease in the absence of 
traditional risk factors. The Multi-Ethnic Study of Atherosclerosis. Atherosclerosis. 2011;214(1):169-73. doi: 10.1016/j.atherosclerosis. 2010.10.011.

26. Satiroglu O, Kocaman SA, Karadag Z, et al. Relationship of the angiographic extent of peripheral arterial disease with coronary artery involvement. J Pak Med Assoc. 2012;62(7):644-9.

27. Radak D, Babic S, Peric M, et al. Distribution of risk factors in patients with premature coronary, supra-aortic branches and peripheral atherosclerotic disease. Med Princ Pract. 2012;21(3):228-33. doi: 10.1159/000334617.

28. Agarwal S, Naderi S. Etiopathogenic differences in coronary artery disease and peripheral artery disease: results from the National Health and Nutrition Examination Survey. Angiology. 2014;65(10):883-90. doi: 10.1177/0003319713509303.

29. Veenstra RP, ter Steege RW, Geelkerken RH, et al. The cardiovascular risk profile of atherosclerotic gastrointestinal ischemia is different from other vascular beds. Am J Med. 2012;125(4):394-8. doi: 10.1016/j.amjmed.2011.09.013.

30. Pająk A, Szafraniec K, Janion M, et al. The impact of the Polish national Programme of Cardiovascular Disease Prevention on the quality of primary cardiovascular disease prevention in clinical practice. Kardiol Pol. 2010;68(12):1332-40.

31. Alvarez LR, Balibrea JM, Suriñach JM, et al. Smoking cessation and outcome in stable outpatients with coronary, cerebrovascular, or peripheral artery disease. Eur J Prev Cardiol. 2013;20(3):486-95. doi: 10.1177/1741826711426090.

32. Hussein AA, Uno K, Wolski K, et al. Peripheral arterial disease and progression of coronary atherosclerosis. $\mathrm{J}$ Am Coll Cardiol. 2011;57(10):1220-5. doi: 10.1016/j.jacc.2010.10.034.

33. Antoniou GA, Fisher RK, Georgiadis GS, et al. Statin therapy in lower limb peripheral arterial disease: Systematic review and meta-analysis. Vascul Pharmacol. 2014;63(2):79-87. doi: 10.1016/j.vph.2014.09.001.
34. Galiñanes EL, Reynolds S, Dombrovskiy VY, Vogel TR. The impact of preoperative statin therapy on open and endovascular abdominal aortic aneurysm repair outcomes. Vascular. 2014;Oct 14. pii: 1708538114552837.

35. Markel A. Statins and peripheral arterial disease. Int Angiol. 2014;

36. Suckow BD, Kraiss LW, Schanzer A, et al. Statin therapy after infrainguinal bypass surgery for critical limb ischemia is associated with improved 5-year survival. J Vasc Surg. 2015;61(1):126-133.e1. doi: 10.1016/j.jvs.2014.05.093.

37. Dosluoglu HH, Davari-Farid S, Pourafkari L, et al.. Statin use is associated with improved overall survival without affecting patency and limb salvage rates following open or endovascular revascularization. Vasc Med. 2014;19 (2):86-93.

38. Sohn MW, Meadows JL, Oh EH, et al. Statin use and lower extremity amputation risk in nonelderly diabetic patients. J Vasc Surg. 2013;58(6):1578-1585.e1. doi: 10.1016/j.jvs.2013.06.069.

39. Aiello FA, Khan AA, Meltzer AJ, et al. Statin therapy is associated with superior clinical outcomes after endovascular treatment of critical limb ischemia. J Vasc Surg. 2012;55(2):371-9. doi: 10.1016/j.jvs.2011.08.044.

Address for correspondence:

Jacek Budzyński, MD, PhD

Clinic of Vascular and Internal Diseases

Jan Biziel University Hospital No. 2 in Bydgoszcz

75 Ujejskiego Street

85-168 Bydgoszcz

Poland

tel./fax: +48523655 148

e-mail: budz@cps.pl

Received: 26.05.2016

Accepted for publication: 10.06.2016 